\title{
Effect of Integrated Exercise Protocol in Lumbar Spinal Stenosis as Compare with Conventional Physiotherapy- A Randomized Control Trial
}

\section{Saurabh Kumar* and Narkeesh A}

Department of Physiotherapy, Punjabi University, Patiala, India

\begin{abstract}
Background context: Lumbar Spinal Stenosis (LSS) is one of the most common spinal pathologies in India. Spinal stenosis is narrowing of the spinal canal with encroachment on the neural structures by surrounding bone and soft tissue. While it is widely held that conservative management should be the first line of approach in patients with LSS, little is known about the efficacy of non-surgical treatments for this condition.
\end{abstract}

Purpose: To compare the specific integrated exercise program with conventional physical therapy programs for patients with LSS.

\section{Study design: Experimental study.}

Method: 30 patients (experimental group, $n=15$; control group, $n=15$ ) with lumbar spinal stenosis were randomized to one of two 3 week physical therapy programs. One program included exercise program (Flexibility exercise, Specific experimental canal enlargement exercise, strengthening exercise, functional/recreational activities), while the other included electrotherapy and exercise program (Hot fomentation, IFT, Flexion Exercises).

Outcome measures: Perceived recovery was assessed with an Oswestry Disability Questionnaire (ODQ). Secondary outcomes included: Numeric Pain Rating Scale (NPRS), Straight Leg Raise, Slump test and Modified Schober Test (MST).

Results: Result shows that the significant improvement in Quality of life, intensity of pain, lumbar ROM and Neural Flexibility was seen in Group A but it was not showing significant results in Group B. This signifies that group A has more significant improvement than Group B.

Conclusion: From the result analysis we found that the integrated exercise approach has a significant effect then a conventional physiotherapy treatment.

Keywords: Lumbar spinal stenosis (LSS); Integrated exercises; Oswestry disability questionnaire (ODQ); Numeric pain rating scale (NPRS); Modified schober test (MST)

\section{Introduction}

Approximately $60 \%$ people of India have been suffering from low back pain. It is of two types: specific or non-specific [1]. Lumbar Spinal Stenosis (LSS) is recognized in about $20 \%$ of patients of LBP while it is attributed to lumbar disk herniation in $80 \%$ of cases [2].

The term spinal stenosis is defined as 'narrowing of the spinal canal with encroachment on the neural structures by surrounding bone and soft tissue' [3]. The effect of spinal canal stenosis becomes important only when it causes interference with the ache, leg pain etc. [4]. LSS can impact a person's quality of life, affect psychosocial wellbeing and significant cause of disability [5]. Spinal canal narrowing can be occur due to degenerative changes of spine which typically involved facet joint hypertrophy, ligamentum flavum thickening, degenerative spondylolisthesis and disc bulging etc. [6]. The signs and symptoms of LSS includes pain, paresthesias, numbness and weakness in the back and legs which occur due to entrapment of the lumbosacral nerve roots in the constricted neural canal and foramina [7].

Neurogenic claudication (NC) is one of the hallmarks of LSS which is described as the classic clinical presentation of progressive onset of radicular pain, paresthesias, numbness, weakness. LSS is classified; according to anatomically and on the basis of its etiology $[8,9]$. Anatomically it is of two types central and lateral; Central stenosis can be caused by posterior disc bulging, thickening of the ligaments, osteophytic outgrowth of the facet joints, degenerative spondylolisthesis and retrolisthesis. Lateral stenosis can be caused by lateral disc bulging, asymmetrical loss of disc height, osteophytic overgrowth of the pedicles and superior lumbar facets.
On the basis of etiology it maybe; Primary stenosis involves narrowing caused by congenital malformations, defects in postnatal development and secondary stenosis, the spinal canal is developmentally normal, but becomes narrowed because of an acquired conditions like degenerative changes, spondylolisthesis, postsurgical scarring, lumbar intervertebral disc herniation, or combinations of these conditions [10]. Another two main is developmental and degenerative [4].

The diagnosis of LSS is based on the clinical history and findings on physical examination and imaging is often necessary in patients with LSS to determine the exact level and the severity of the stenosis [6,11]. MRI or CT scan is widely used diagnostic tools which confirm the presence of spinal stenosis [12]. The Radiological criteria for lumbar spinal stenosis (L1 to L5) according to location of the stenosis through MRI [13].

1. Central canal stenosis: Anterior - posterior diameter of spinal canal $\leq 12 \mathrm{~mm}$.

2. Lateral recess stenosis: lateral recess height $\leq 3 \mathrm{~mm}$ or lateral recess depth $\leq 5 \mathrm{~mm}$.

*Corresponding author: Saurabh Kumar, Department of Physiotherapy, Punjabi University, Patiala, India, Tel: +919023245955; E-mail: saurabh04pt@gmail.com

Received August 12, 2017; Accepted December 05, 2017; Published December 12,2017

Citation: Kumar S, Narkeesh A (2017) Effect of Integrated Exercise Protocol in Lumbar Spinal Stenosis as Compare with Conventional Physiotherapy- A Randomized Control Trial. Int J Neurorehabilitation 4: 301. doi: 10.4172/23760281.1000301

Copyright: @ 2017 Kumar S, et al. This is an open-access article distributed under the terms of the Creative Commons Attribution License, which permits unrestricted use, distribution, and reproduction in any medium, provided the original author and source are credited. 


\section{Foraminal stenosis: Foraminal diameter $\leq 5 \mathrm{~mm}[10]$.}

A variety of conservative and non-conservative treatments are used for the treatment of LSS. In some cases surgical techniques are preferred to treat patients with LSS in which persistent symptoms are not adequately controlled by conservative/therapeutic modalities [14]. The Conservative management includes NSAIDS and exercise programs to strengthen musculature surrounding the low back region [15]. Physical therapy is accepted conservative [16]. There are lack of evidence in support of commonly utilized conservative interventions continues to result in lack of clarity regarding what intervention should be utilized to manage patients with LSS [17]. So, there is a need to establish the optimal rehabilitation treatment strategy for lumbar stenosis patients, as the comprehensive non-operative treatment provides better results to manage the LSS which improve the health status of the patient with least side effects and problems [18].

So the aim of the present study is to find out the effect of integrated exercise protocol on LSS as compared with conventional treatment.

\section{Materials and Method}

Nature of the present study is a Randomized Control Trial (RCT). The method of sampling was random sampling. 30 subjects between the age group of 25-50 years diagnosed as a Lumbar Spinal Stenosis through MRI Findings (AP diameter $\leq 12 \mathrm{~mm}$ ) were included in the study. We determined the total random sample of $\mathrm{n}=30$ [Group $\mathrm{A}$, (experimental group) $\mathrm{n}=15$ and Group $\mathrm{B}$ (control group) $\mathrm{n}=15$ ] considering the following inclusion criteria

1. Age group 25-50 years.

2. Patient with Low back pain with or without leg pain.

3. Diagnosed case from an Expert and confirmed by medical history review.

4. MRI: lumbar spinal stenosis antero-postero diameter $\leq 12 \mathrm{~mm}$ Patients meeting any of the following criteria were excluded:

1. Patient with Spinal surgery.

2. Patient with Cognitive alteration.

3. Non-cooperative patient.

4. Any concurrent major disease such as cancer, diabetes, renal failure, tumor.

\section{Pregnancy}

Before the commencement of the study, each subject included in the study was given information about the study and after attaining their interest, a written consent was signed from every participant. The protocols and research methodology and sample collection were approved by the department and ethical committee of physiotherapy Punjabi university Patiala, Punjab. All baseline information was obtained before randomization. Patients were scheduled for 45 to 60 min physical therapy sessions over 3 weeks ( 5 days a week). For one group Flexibility exercise, Specific experimental canal enlargement exercise, strengthening exercise, functional or Re-creational activities and for other group hot outcome measures (Perceived recovery was assessed with an Oswestry Disability Questionnaire (ODQ). Secondary outcomes included: Numeric Pain Rating Scale (NPRS), Straight Leg Raise (by goniometer), Slump test (by goniometer) and Modified Schober Test (MST) were recorded on $11^{\text {th }}$ day of intervention and $22^{\text {nd }}$ day of post intervention (Table 1).

\section{Results}

Data was analysed with appropriate statistical tool using SPSS version 20.0 for window 7 were included in the study, the majority of subjects were males 20 patients (66.7\%) and only 10 patients $(33.3 \%)$ were female. Mean age is $38.53 \pm 8.37$. Independent t-test used to evaluate the significance of difference between mean of two quantitative variables. The cut of level of significance was set at $\alpha=0.05$ (Figures 1-6).
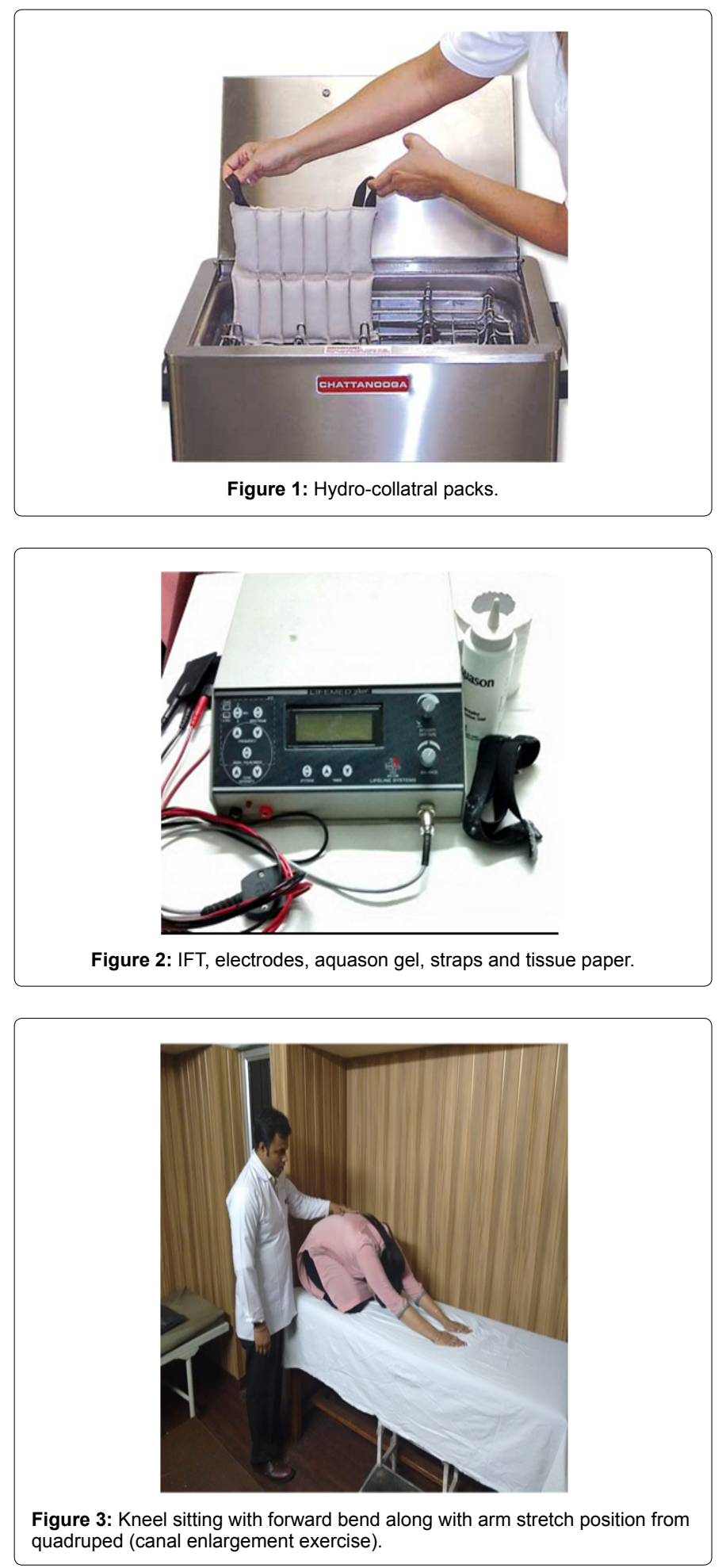
Citation: Kumar S, Narkeesh A (2017) Effect of Integrated Exercise Protocol in Lumbar Spinal Stenosis as Compare with Conventional PhysiotherapyA Randomized Control Trial. Int J Neurorehabilitation 4: 301. doi: 10.4172/2376-0281.1000301

Page 3 of 6

\begin{tabular}{|c|c|c|c|c|c|c|}
\hline & & STAGE I & STAGE II & STAGE III & STAGE & E IV \\
\hline & & Flexibility Exercises & $\begin{array}{l}\text { Specific Experimental Canal } \\
\text { enlargement Ex. }\end{array}$ & Stabilization/strengthening Exercises & Functional/Regair & ning Activities \\
\hline \multirow{5}{*}{ Week 1} & Day 1 & $\begin{array}{l}\text { Heel sliding in supine, spinal } \\
\text { rotation } 10 \text { Rep each side }\end{array}$ & - no- & - no- & - no- & - no- \\
\hline & Day 2 & $\begin{array}{l}\text { Heel sliding in supine, spinal } \\
\text { rotation } 10 \text { Rep each side }\end{array}$ & - no- & - no- & - no- & -no- \\
\hline & Day 3 & $\begin{array}{l}\text { Heel sliding in supine, spinal } \\
\text { rotation } 10 \text { Rep each side }\end{array}$ & $\begin{array}{l}\text { Knee to chest (single leg, double leg), } \\
3-5 \text { rep with } 10 \text { s hold }\end{array}$ & - no- & - no- & - no- \\
\hline & Day 4 & $\begin{array}{l}\text { Heel sliding in supine, spinal } \\
\text { rotation } 10 \text { Rep each side }\end{array}$ & $\begin{array}{l}\text { Knee to chest (single leg, double } \\
\text { leg), kneel sitting with forward bend } \\
\text { along with arm stretch position from } \\
\text { quadruped (3-5 Rep. } 10 \text { s hold) }\end{array}$ & - no- & - no- & - no- \\
\hline & Day 5 & $\begin{array}{l}\text { Heel sliding in supine, spinal } \\
\text { rotation } 10 \text { Rep each side }\end{array}$ & $\begin{array}{l}\text { Knee to chest (single leg, double } \\
\text { leg), kneel sitting with forward bend } \\
\text { along with arm stretch position from } \\
\text { quadruped (3-5 Rep. } 10 \text { s hold) }\end{array}$ & Pelvic bridging ( 3 to 5 rep with $10 \mathrm{~s}$ hold) & - no- & -no- \\
\hline \multirow{5}{*}{ Week 2} & Day 1 & $\begin{array}{c}\text { Spinal rotation (10 Rep each side), } \\
\text { Hamstring flexibility, Piriformis } \\
\text { flexibility (3-5 Rep. } 30 \text { s hold) }\end{array}$ & $\begin{array}{l}\text { Knee to chest (single leg, double } \\
\text { leg), kneel sitting with forward bend } \\
\text { along with arm stretch position from } \\
\text { quadruped (3-5 Rep. } 10 \text { s hold) }\end{array}$ & $\begin{array}{l}\text { Pelvic bridging Strengthening of gluteus } \\
\text { medius in side lying ( } 3 \text { to } 5 \text { rep with } 10 \mathrm{~s} \\
\text { hold) }\end{array}$ & - no- & -no- \\
\hline & Day 2 & $\begin{array}{l}\text { Spinal rotation (10 Rep each side), } \\
\text { Hamstring flexibility, Piriformis } \\
\text { flexibility (3-5 Rep. } 30 \text { s hold) }\end{array}$ & $\begin{array}{l}\text { Knee to chest (single leg, double } \\
\text { leg), kneel sitting with forward bend } \\
\text { along with arm stretch position from } \\
\text { quadruped, LIONS position (5-7 Rep. } \\
10 \text { s hold) }\end{array}$ & $\begin{array}{l}\text { Pelvic bridging Strengthening of gluteus } \\
\text { medius in side lying ( } 3 \text { to } 5 \text { rep with } 10 \mathrm{~s} \\
\text { hold) }\end{array}$ & $\begin{array}{l}\text { Walk inside room for } \\
1 \text { or } 2 \text { min increase } \\
\text { upto } 5 \text { to } 10 \text { min as } \\
\text { per the pain severity }\end{array}$ & -no- \\
\hline & Day 3 & $\begin{array}{l}\text { Spinal rotation (10 Rep each side), } \\
\text { Hamstring flexibility, Piriformis } \\
\text { flexibility (3-5 Rep. } 30 \text { s hold) }\end{array}$ & $\begin{array}{l}\text { Knee to chest (single leg, double } \\
\text { leg), kneel sitting with forward bend } \\
\text { along with arm stretch position from } \\
\text { quadruped, LIONS position (5-7 Rep. } \\
10 \text { s hold) }\end{array}$ & $\begin{array}{l}\text { Pelvic bridging Strengthening of gluteus } \\
\text { medius in side lying ( } 3 \text { to } 5 \text { rep with } 10 \mathrm{~s} \\
\text { hold) }\end{array}$ & $\begin{array}{l}\text { Walk inside room for } \\
1 \text { or } 2 \text { min increase } \\
\text { upto } 5 \text { to } 15 \text { min as } \\
\text { per the pain severity }\end{array}$ & -no- \\
\hline & Day 4 & $\begin{array}{l}\text { Spinal rotation (10 Rep each side), } \\
\text { Hamstring flexibility, Piriformis } \\
\text { flexibility (5-7 Rep. } 30 \text { s hold) }\end{array}$ & $\begin{array}{l}\text { Knee to chest (single leg, double } \\
\text { leg), kneel sitting with forward bend } \\
\text { along with arm stretch position from } \\
\text { quadruped, LIONS position (5-7 Rep } \\
10 \text { s hold) }\end{array}$ & $\begin{array}{l}\text { Pelvic bridging Strengthening of gluteus } \\
\text { medius in side lying), Sacrum counter } \\
\text { nutation ( } 5 \text { to } 7 \text { rep with } 10 \mathrm{~s} \text { hold) }\end{array}$ & $\begin{array}{l}\text { Walk } 100-300 \mathrm{~m}(2 \\
\text { times/day) } \\
\text { Start ADLs light to } \\
\text { moderate }\end{array}$ & -no- \\
\hline & Day 5 & $\begin{array}{l}\text { Spinal rotation(10 Rep each side), } \\
\text { Hamstring flexibility, Piriformis } \\
\text { flexibility (5-7 Rep. } 30 \mathrm{~s} \text { hold) }\end{array}$ & $\begin{array}{l}\text { Knee to chest (single leg, double } \\
\text { leg), kneel sitting with forward bend } \\
\text { along with arm stretch position from } \\
\text { quadruped, LIONS position (5-7 Rep. } \\
10 \mathrm{~s} \text { hold). }\end{array}$ & $\begin{array}{l}\text { Pelvic bridging Strengthening of gluteus } \\
\text { medius in side lying), Sacrum counter } \\
\text { nutation ( } 5 \text { to } 7 \text { rep with } 10 \mathrm{~s} \text { hold) }\end{array}$ & $\begin{array}{l}\text { Walk } 200-500 \text { m (2 } \\
\text { times/day) } \\
\text { Start ADLs light to } \\
\text { moderate }\end{array}$ & -no- \\
\hline \multirow{5}{*}{ Week 3} & Day 1 & $\begin{array}{c}\text { Spinal rotation (10 Rep each side), } \\
\text { Hamstring flexibility, Piriformis } \\
\text { flexibility, IT band flexibility, } \\
\text { Quadratus lumborum (5-7 Rep } 30 \\
\text { s hold), llio psoas release }\end{array}$ & $\begin{array}{l}\text { Knee to chest (single leg, double } \\
\text { leg), kneel sitting with forward bend } \\
\text { along with arm stretch position from } \\
\text { quadruped. Cat and camel, LIONS } \\
\text { position (5-7 Rep } 10 \text { s hold) }\end{array}$ & $\begin{array}{l}\text { Pelvic bridging Strengthening of gluteus } \\
\text { medius in side lying, Sacrum counter } \\
\text { nutation, Posterior pelvic tilting ( } 5 \text { to } 7 \text { rep } \\
\text { with } 10 \text { s hold), Abdominal prep, Quadruped } \\
\text { arm and leg lifts (3-5 Rep } 10 \text { s hold) }\end{array}$ & $\begin{array}{l}\text { Walk } 200-500 \mathrm{~m}(2 \\
\text { times/day) } \\
\text { Start ADLs light to } \\
\text { moderate }\end{array}$ & $\begin{array}{l}\text { Dual task } \\
\text { activity focus } \\
\text { on core muscle } \\
\text { and functional } \\
\text { activity }\end{array}$ \\
\hline & Day 2 & $\begin{array}{l}\text { Spinal rotation (10 Rep each side), } \\
\text { Hamstring flexibility, Piriformis } \\
\text { flexibility, IT band flexibility, } \\
\text { Quadratus lumborum (5-7 Rep } 30 \\
\text { s hold), llio psoas release }\end{array}$ & $\begin{array}{l}\text { Knee to chest (single leg, double } \\
\text { leg), kneel sitting with forward bend } \\
\text { along with arm stretch position from } \\
\text { quadruped. Cat and camel, LIONS } \\
\text { position. (5-7 Rep } 10 \mathrm{~s} \text { hold) }\end{array}$ & $\begin{array}{l}\text { Pelvic bridging Strengthening of gluteus } \\
\text { medius in side lying, Sacrum counter } \\
\text { nutation, Posterior pelvic tilting ( } 5 \text { to } 7 \text { Rep } \\
\text { with } 10 \mathrm{~s} \text { hold), Abdominal prep, Quadruped } \\
\text { arm and leg lifts (3-5 Rep } 10 \mathrm{~s} \text { hold) }\end{array}$ & $\begin{array}{l}\text { Walk } 500-700 \mathrm{~m}(2 \\
\text { times/day) } \\
\text { Start ADLs light to } \\
\text { moderate }\end{array}$ & $\begin{array}{l}\text { Dual task } \\
\text { activity focus } \\
\text { on core and } \\
\text { functional } \\
\text { activity }\end{array}$ \\
\hline & Day 3 & $\begin{array}{l}\text { Spinal rotation (10 Rep each side), } \\
\text { Hamstring flexibility, Piriformis } \\
\text { flexibility, IT band flexibility, } \\
\text { Quadratus lumborum (5-10 Rep } \\
30 \text { s hold), llio psoas release }\end{array}$ & $\begin{array}{l}\text { Knee to chest (single leg, double } \\
\text { leg), kneel sitting with forward bend } \\
\text { along with arm stretch position from } \\
\text { quadruped. Cat and camel, LIONS } \\
\text { position. (5-10 Rep } 10 \mathrm{~s} \text { hold) }\end{array}$ & $\begin{array}{l}\text { Pelvic bridging Strengthening of gluteus } \\
\text { medius in side lying, Sacrum counter } \\
\text { nutation, Posterior pelvic tilting ( } 5 \text { to } 10 \text { Rep } \\
\text { with } 10 \text { s hold), Abdominal prep, Quadruped } \\
\text { arm and leg lifts (3-5 Rep } 10 \text { s hold) }\end{array}$ & $\begin{array}{l}\text { Walk } 500-700 \mathrm{~m}(2 \\
\text { times/day) } \\
\text { Start ADLs light to } \\
\text { moderate }\end{array}$ & $\begin{array}{l}\text { Dual task } \\
\text { activity focus } \\
\text { on core and } \\
\text { functional } \\
\text { activity }\end{array}$ \\
\hline & Day 4 & $\begin{array}{l}\text { Spinal rotation (10 Rep each side), } \\
\text { Hamstring flexibility, Piriformis } \\
\text { flexibility, IT band flexibility, } \\
\text { Quadratus lumborum (5-10 Rep } \\
30 \text { s hold), llio psoas release }\end{array}$ & $\begin{array}{l}\text { Knee to chest (single leg, double } \\
\text { leg), kneel sitting with forward bend } \\
\text { along with arm stretch position from } \\
\text { quadruped. Cat and camel, LIONS } \\
\text { position. (5-10 Rep } 10 \mathrm{~s} \text { hold) }\end{array}$ & $\begin{array}{l}\text { Pelvic bridging Strengthening of gluteus } \\
\text { medius in side lying, Sacrum counter } \\
\text { nutation, Posterior pelvic tilting ( } 5 \text { to } 10 \text { Rep } \\
\text { with } 10 \text { s hold), Abdominal prep, Quadruped } \\
\text { arm and leg lifts (5-10 Rep } 10 \text { s hold) }\end{array}$ & $\begin{array}{l}\text { Walk } 1 \mathrm{~km}(2 \text { times/ } \\
\text { day }) \\
\text { Start ADLs light to } \\
\text { moderate }\end{array}$ & $\begin{array}{l}\text { Play badminton } \\
\text { for 10-20 min }\end{array}$ \\
\hline & Day 5 & $\begin{array}{l}\text { Spinal rotation (10 Rep each side), } \\
\text { Hamstring flexibility, Piriformis } \\
\text { flexibility, IT band flexibility, } \\
\text { Quadratus lumborum (5-10 Rep } \\
30 \text { s hold), llio psoas release }\end{array}$ & $\begin{array}{l}\text { Knee to chest (single leg, double } \\
\text { leg), kneel sitting with forward bend } \\
\text { along with arm stretch position from } \\
\text { quadruped. Cat and camel, LIONS } \\
\text { position. (5-10 Rep } 10 \mathrm{~s} \text { hold) }\end{array}$ & $\begin{array}{l}\text { Pelvic bridging Strengthening of gluteus } \\
\text { medius in side lying, Sacrum counter } \\
\text { nutation, Posterior pelvic tilting ( } 5 \text { to } 10 \text { Rep } \\
\text { with } 10 \text { s hold), Abdominal prep, Quadruped } \\
\text { arm and leg lifts (5-10 Rep } 10 \mathrm{~s} \text { hold) }\end{array}$ & $\begin{array}{l}\text { Walk } 1 \mathrm{~km}(2 \text { times/ } \\
\text { day }) \\
\text { Start ADLs light to } \\
\text { moderate }\end{array}$ & $\begin{array}{l}\text { Play badminton } \\
\text { for 10-20 min }\end{array}$ \\
\hline
\end{tabular}

NOTE:

- If pain is severing use ICE PACKS

- Depend on the pain status the repetition may reduce or stop by physiotherapist /researcher/PI

- All the exercises have to be done with normal breathing.

- In strengthening exercises core muscle should be engaged.

- If patient can't perform exercise, the exercises will shift to another day.

Table 1: The therapist gave the treatment protocol of 21 days ( 20 to 40 mins per day for five days a week for three weeks) under his observation which was described as follows 


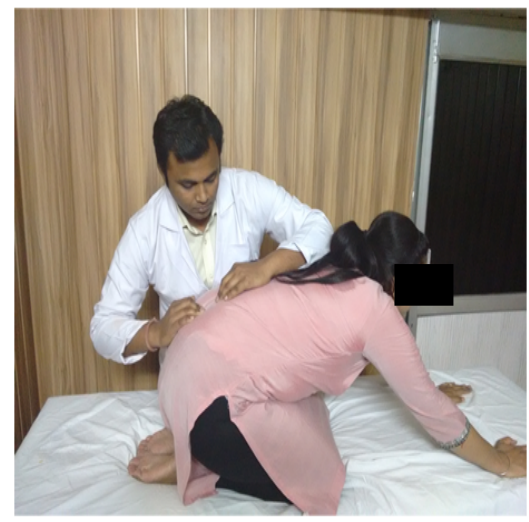

Figure 4: LIONS: Position with neck extension-starting position (for neural flexibility).

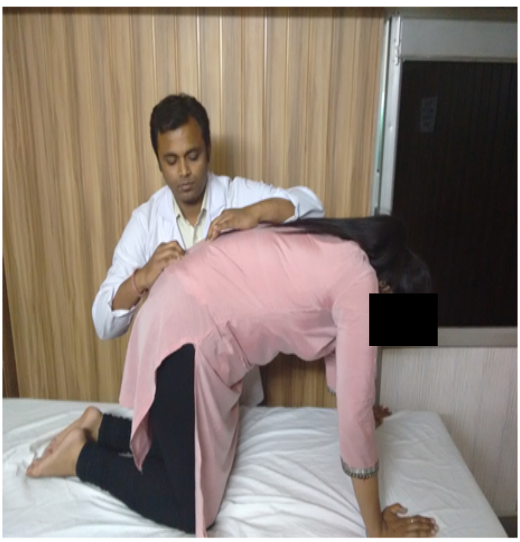

Figure 5: LIONS: Position with neck flexion-end position.

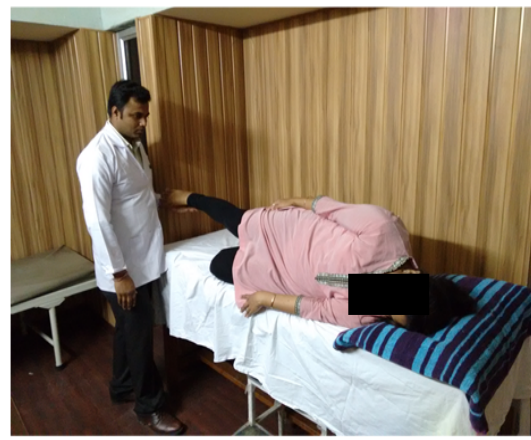

Figure 6: Strengthening of gluteus medius muscle.

Table 2 presents the improvement in QOL in ODQ measure by the two interventions used in the study. The Mean and SD on Pre intervention and post intervention at $11^{\text {th }}$ and $22^{\text {nd }}$ day for Group A was $61.29 \pm 12.87,42.77 \pm 7.90$ and $20.41 \pm 4.76$, respectively. In Group $\mathrm{B}$, intervention and post intervention at $11^{\text {th }}$ and $22^{\text {nd }}$ day respectively. The mean difference between pre intervention and post intervention at $22^{\text {nd }}$ day of group A and Group B was $40.87 \pm 10.81$ and $7.26 \pm 4.56$, respectively (Figure 7).

Table 3 shows the Comparison of ODQ mean value at Pre, $11^{\text {th }}$ day, $22^{\text {nd }}$ day and their MD (Pre $-22^{\text {nd }}$ day) between Group A and Group $\mathrm{B}$ at $95 \%$ level of significance. The $t$ value at pre and post intervention at $11^{\text {th }}$ and $22^{\text {nd }}$ day was $0.306,-2.953$ and -7.343 respectively between ODQ scores of Group A and Group B. The Mean Difference for Group A Vs. Group B was 11.096 which signifies that group A has more significant improvement than Group B.

Table 4 presents the improvement in Pain in NPRS measure by the two interventions used in the study. The Mean and SD on Pre intervention and post intervention at $11^{\text {th }}$ and $22^{\text {nd }}$ day for Group A was $7.60 \pm 0.99,4.93 \pm 0.80$ and $2.13 \pm 0.83$, respectively. In Group B, the mean and SD value of NPRS was $6.73 \pm 1.58,6.13 \pm 1.46$ and $5.40 \pm 1.45$ at pre intervention and post intervention at $11^{\text {th }} \& 22^{\text {nd }}$ day, respectively. The mean difference between pre intervention and post intervention at $22^{\text {nd }}$ day of group A and Group B was $5.47 \pm 0.64$ and $1.33 \pm 0.49$ respectively. Data graphically shown in Figure 8 which is as follow:

Table 5 shows the Comparison of NPRS mean value at Pre, $11^{\text {th }}$ day, $22^{\text {nd }}$ day and their MD (Pre $-22^{\text {nd }}$ day) between Group A and Group $B$ at $95 \%$ level of significance. The $t$ value at pre and post intervention at $11^{\text {th }}$ and $22^{\text {nd }}$ day was $1.803,-2.797$ and -7.548 , respectively between ODQ scores of Group A and Group B. The Mean Difference for Group A Vs. Group B was 19.892 which signifies that group A has more significant improvement than Group B.

\begin{tabular}{|l|c|c|c|c|}
\hline \multirow{2}{*}{ ODQ Evaluation } & \multicolumn{2}{|c|}{ GROUP A } & \multicolumn{2}{c|}{ GROUP B } \\
\cline { 2 - 5 } & Mean & SD & Mean & SD \\
\hline Pre & 61.29 & 12.87 & 59.51 & 18.37 \\
\hline $11^{\text {th }}$ day & 42.77 & 7.90 & 58.03 & 18.40 \\
\hline $22^{\text {nd }}$ day & 20.41 & 4.76 & 52.25 & 16.10 \\
\hline MD (Pre - 22 ${ }^{\text {nd }}$ day) & 40.87 & 10.81 & 7.26 & 4.56 \\
\hline
\end{tabular}

Table 2: Mean and SD of oswestry disability questionnaire (ODQ) scores at pre intervention, post-intervention at $11^{\text {th }}$ day and $22^{\text {nd }}$ day and their mean difference (Pre $-22^{\text {nd }}$ day) of the subjects of group $A$ and group $B$.

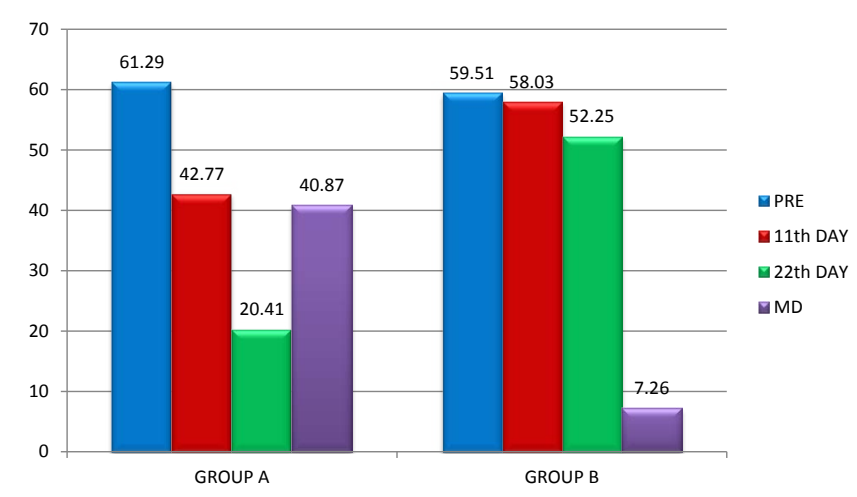

Figure 7: Shows the comparison of mean value for ODQ at pre Interval, $11^{\text {th }}$ day and $22^{\text {nd }}$ day between Group A and Group B.

\begin{tabular}{|l|c|}
\hline \multirow{2}{*}{ ODQ Evaluation } & GROUP A Vs. GROUP B \\
\cline { 2 - 2 } & $\mathbf{t}$ value \\
\hline $11^{\text {th }}$ day & 0.306 \\
\hline $22^{\text {nd }}$ day & $-2.953^{*}$ \\
\hline (Pre $-22^{\text {nd }}$ day) & $-7.343^{*}$ \\
\hline
\end{tabular}

${ }^{*} \mathrm{p}<0.05=$ Significant

Table 3: Comparison of ODQ mean value at Pre, $11^{\text {th }}$ day, $22^{\text {nd }}$ day and MD (Pre $22^{\text {nd }}$ day) between group $A$ and group $B$. 
Table 6 shows the Comparison of MST mean value at Pre, $11^{\text {th }}$ day, $22^{\text {nd }}$ day and their MD (Pre $-22^{\text {nd }}$ day) between Group A and Group B at $95 \%$ level of significance. The $t$ value at pre and post intervention at $11^{\text {th }}$ and $22^{\text {nd }}$ day was $0.306,2.267$ and 5.367 respectively between MST scores of Group A and Group B. The Mean Difference for Group A Vs. Group B was 3.895 which signifies that group A has more significant improvement than Group B.

Table 7 shows the Comparison of SLR mean value on right and left leg respectively at Pre, $11^{\text {th }}$ day, $22^{\text {nd }}$ day and their MD (Pre $-22^{\text {nd }}$ day) between Group A and Group B at 95\% level of significance. The t value of SLR score for the right leg at pre and post intervention at $11^{\text {th }}$ and $22^{\text {nd }}$ day was $1.333,2.076$ and 3.758 and for the left leg $0.075,2.343$ and 4.691, respectively between SLR scores on right leg of Group A and Group B. The Mean Difference for Group A Vs. Group B for right leg was 1.581 and for left leg was 2.837 , respectively, which signifies that group A has more significant improvement than Group B.

Table 8 shows the Comparison of ST mean value on right leg and left leg at Pre, $11^{\text {th }}$ day, $22^{\text {nd }}$ day and their MD (Pre $-22^{\text {nd }}$ day) respectively between Group A and Group B at 95\% level of significance. The $t$ value of right leg at pre and post intervention at $11^{\text {th }} \& 22^{\text {nd }}$ day was $1.428,-0.830$ and -3.510 and for the left leg $1.414,0.000$ and -3.136 respectively where ST scores of Group A and Group B at pre and $11^{\text {th }}$ day

\begin{tabular}{|l|c|c|c|c|}
\hline \multirow{2}{*}{ NPIS } & \multicolumn{2}{|c|}{ GROUP A } & \multicolumn{2}{c|}{ GROUP B } \\
\cline { 2 - 5 } & Mean & SD & Mean & SD \\
\hline Pre & 7.60 & 0.99 & 6.73 & 1.58 \\
\hline $11^{\text {th }}$ day & 4.93 & 0.80 & 6.13 & 1.46 \\
\hline $22^{\text {nd }}$ day & 2.13 & 0.83 & 5.40 & 1.45 \\
\hline MD (Pre $-22^{\text {nd }}$ day) & 5.47 & 0.64 & 1.33 & 0.49 \\
\hline
\end{tabular}

Table 4: Mean and SD of numeric pain rating scale (NPRS) at Pre, $11^{\text {th }}$ day, $22^{\text {nd }}$ day and MD (Pre $-22^{\text {nd }}$ day) for the subjects of group A and group B.

\begin{tabular}{|l|c|}
\hline \multirow{2}{*}{ NPRS } & GROUP A vs. GROUP B \\
\cline { 2 - 2 } & $\mathbf{t}$ value \\
\hline $11^{\text {th }}$ day & 1.803 \\
\hline $22^{\text {nd }}$ day & $-2.797^{*}$ \\
\hline Pre $-22^{\text {nd }}$ day) & $-7.548^{*}$ \\
\hline
\end{tabular}

\section{${ }^{*} \mathrm{p}<0.05=$ Significant}

Table 5: Comparison of mean value for NPRS at Pre, $11^{\text {th }}$ day, $22^{\text {nd }}$ day and MD (Pre $-22^{\text {nd }}$ day) between group A and group $B$.

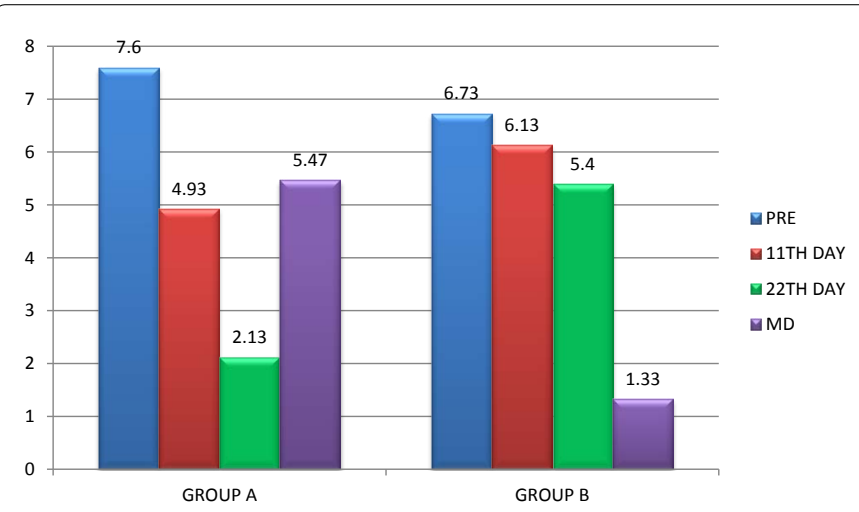

Figure 8: Shows the comparison of mean value for NPRS at pre interval, $11^{\text {th }}$ day and $22^{\text {nd }}$ day between Group A and Group B.

\begin{tabular}{|l|c|}
\hline \multirow{2}{*}{ MST } & GROUP A vs. GROUP B \\
\hline Pre & t value \\
\hline $11^{\text {th }}$ day & 0.306 \\
\hline $22^{\text {nd }}$ day & $2.267^{*}$ \\
\hline Pre $-22^{\text {nd }}$ day) & $5.367^{*}$ \\
\hline
\end{tabular}

${ }^{*} \mathrm{p}<0.05=$ Significant

Table 6: Comparison of mean value for modified Schober test (MST) at Pre, $11^{\text {th }}$ day, $22^{\text {nd }}$ day and $M D$ (Pre $-22^{\text {nd }}$ day) between group $A$ and

\begin{tabular}{|l|c|c|}
\hline \multirow{2}{*}{ SLR } & \multicolumn{2}{|c|}{ GROUP A vs. GROUP B } \\
\cline { 2 - 3 } & \multicolumn{2}{|c|}{ t-value } \\
\cline { 2 - 3 } & SLR Right & SLR Left \\
\hline Pre & 1.333 & 0.075 \\
\hline $21^{\text {th }}$ day & 2.076 & $2.343^{*}$ \\
\hline (Pre $-22^{\text {nd }}$ day) & $3.758^{*}$ & $4.691^{*}$ \\
\hline
\end{tabular}

${ }^{*} \mathrm{p}<0.05=$ Significant

Table 7: Comparison of mean value for straight leg raise (SLR) Right at Pre, $11^{\text {th }}$ day, $22^{\text {nd }}$ day and MD (Pre $-22^{\text {nd }}$ day) between group $A$ and group $B$.

\begin{tabular}{|l|c|c|}
\hline \multirow{2}{*}{ ST } & \multicolumn{2}{|c|}{ GROUP A vs. GROUP B } \\
\cline { 2 - 3 } & \multicolumn{2}{|c|}{ t value } \\
\cline { 2 - 3 } & Right Leg & Left \\
\hline Pre & 1.428 & 1.414 \\
\hline $11^{\text {th }}$ day & -0.830 & 0.000 \\
\hline $22^{\text {nd }}$ day & $-3.510^{*}$ & $-3.136^{*}$ \\
\hline (Pre $-22^{\text {nd }}$ day) & $6.564^{*}$ & $5.314^{*}$ \\
\hline
\end{tabular}

${ }^{*} \mathrm{p}<0.05=$ Significant

Table 8: Comparison of mean value for slump test (ST) right at Pre, $11^{\text {th }}$ day, $22^{\text {nd }}$ day and MD (Pre $-22^{\text {nd }}$ day) between group $A$ and group $B$.

show no significant improvement whereas $22^{\text {nd }}$ day shows significant improvement for both right and left leg. The Mean Difference for Group A Vs. Group B for right leg was 6.564 and for the left leg was 5.314 respectively, which signifies that group A has more significant improvement than Group B.

\section{Discussion}

Lumbar MRI was the standard procedure for the demonstration of stenosis [19]. In the present study, a total 30 subjects with mean age (in years) $38.53 \pm 8.37$ were participated in the study in which 10 were females and 20 were males. The Mean and SD of age (in years) for Group A (Experimental) and Group B (Control) were $37.47 \pm 7.78$ and $39.60 \pm 9.08$, respectively. The mean age of the subjects included in the study signifies that LSS were commonly occur after the $3^{\text {rd }}$ decade of life while physiology supports that the LSS commonly occurs after the $6^{\text {th }}$ decade of life as a result of degeneration. The reason behind the early occurrence of LSS was sedentary lifestyle, occupation, smoking habit and ergonomically challenges posture [20].

The present findings were similarly attained by the Reiman et al. [17], in his systematic review which shows that by using TENS to improve intensity of pain among LSS patient. In Group A, Cryotherapy was used to improve the intensity of pain among LSS patient. The application of cryotherapy reduces the intensity of pain by the means of pain gate mechanism and also decrease the inflammatory response associated with cause of LSS [21]. Cryotherapy was helpful in relieving in decreasing intensity of pain among Low back pain. The similar findings 
were observed by the Dehghan and Farahbod [22]. The conventional physiotherapy management was mainly focused on electrotherapeutic modalities and least on exercise therapy whereas integrated exercise protocol was based on cryotherapy and exercise regime to improve the spinal stability through strengthening the muscles. Present study was done to find out that an integrated exercise protocol was better than the conventional physiotherapy management for LSS patients. In group $\mathrm{B}$, to improve the ROM of the Lumbar spine, the electrotherapeutic modalities along the exercises like knee to chest, pelvic rotation and pelvic bridging were used. It causes the stretching of para-spinal musculature and helps in improving lumbar ROM. there was a significant difference between the base line and post intervention score on MST i.e. there was improvement in ROM of lumbar flexion in group B. it was supported by Creighton et al. [9] and Reiman et al. [17] in their studies. There was a significant difference between the base line and post intervention score on MST i.e. there was improvement in ROM lumbar flexion in group A. The Straight Leg Raise (SLR) and Slump test was a common neurodynamic test used to examine the mechano-sensitivity of the lower extremity nervous system in individuals with low back or lower extremity pain $[23,24]$. So, in the present study, Slump test and SLR Neural Flexibility was used as an outcome measure to evaluate the effectiveness of conventional physiotherapy management and integrated exercise protocol on neural flexibility among LSS patients. There was a significant difference between the base line and post intervention score on SLR right and left leg i.e. there was improvement in neural flexibility in group B. That there was a significant difference between the base line and post intervention score on ST right and left leg i.e. there was improvement in neural flexibility in group B.

The QOL of the patients was hampered in LSS patients due to pain and associated symptoms which leads person dependent on others for their ADL's. In the Present Study, the Oswestry Disability Questioner (ODQ) was used to measure the disability occur due to LSS on the 5 levels of disability. It reveals that there was a significant difference between the base line and post intervention score on ODQ i.e. there was improvement in QOL in group B. It reveals that there was a significant difference between the base line and post intervention score on ODQ i.e. there was improvement in QOL in group A. The present findings were similarly attained by some researchers who concluded that the lumbar flexion exercises has been helpful in improving Quality of life of LSS patient. Creighton et al. [9] and Fritz et al. [25] shows significant physiotherapy intervention has effect in improvement of Quality of life among LSS patient.

\section{Conclusion}

In the present study the effect of an integrated approach and conventional physiotherapy treatment on LSS patient was evaluated. It has been found that the integrated exercise approach has a significant effect in improving pain, lumbar ROM, neural flexibility and Disability then a conventional physiotherapy treatment. So it has been concluded from the present study that the integrated exercise approach was better than conventional physiotherapy treatment.

\section{References}

1. Koley S, Singh G, Sandhu R (2008) Severity of disability in elderly patients with low back pain in Amritsar, Punjab. Kamla-Raj: 10: 265-268.

2. Samini F, Gharedaghi M, Khajavi M, Samini M (2014) The etiologies of low back pain in patients with lumbar disk herniation. Iran Red Crescent Med J 16: e15670.
3. Weinstein JN, Tosteson TD, Lurie JD, Tosteson ANA, Blood E, et al. (2008) Surgical versus non-surgical therapy for lumbar spinal stenosis. N Engl J Med 358: 794-810.

4. Ahmad T, Goel P, Babu CSR (2011) A study of lumbar canal by M.R.I. in clinically symptomatic and asymptomatic subjects. J Anat Soc India 60: 184-187.

5. Jarrett MS, Orlando JF, Somers KG (2012) The effectiveness of land based exercise compared to decompressive surgery in the management of lumbar spinal-canal stenosis: A systemic review. BMC Musculoskelet Disord 13: 30.

6. Mazanec DJ, Podichetty VK, Hsia A (2002) Lumbar canal stenosis: Start with nonsurgical therapy. Cleve Clin J Med 69: 909-917.

7. Binder DK, Schmidt MH, Weinstein PR (2002) Lumbar spinal stenosis. Semin Neurol 22: 157-165.

8. Murphy DR, Hurwitz EL, Gregory AA, Clary R (2006) A non-surgical approach to the management of lumbar spinal stenosis: A prospective observational cohort study. BMC Musculoskelet Disord 7: 16

9. Creighton DS, Krauss J, Marcoux B (2006) Management of lumbar spinal stenosis through the use of translatoric manipulation and lumbar flexion exercises: A case series. J Man Manip Ther 14: E1-E10.

10. Fritz JM, Delitto A, Welch WC, Erhard RE (1998) Lumbar spinal stenosis: A review of current concepts in evaluation, management and outcome measurements. Arch Phys Med Rehabil 79: 700-708.

11. Saleh A, Sadeghpour R. Kang KK (2013) Degenerative lumbar spinal stenosis: Diagnosis and management. J SPINE S2: 005

12. Katz JN, Harris MB (2008) Clinical practice. Lumbar spinal stenosis. N Engl J Med 358: 818-825.

13. Steurer J, Nydegger A, Held U, Brunner F, Hodler J, et al. (2010) Lumbsten: The lumbar spinal stenosis outcome study. BMC Musculoskelet Disord 11: 254

14. Genavay S, Atlas SJ (2010) Lumbar spinal stenosis. Best Pract Res Clin Rheumatol 24: 253-265.

15. Ciricillo SF, Weinstein PR (1993) Lumbar spinal stenosis. West J Med 158 171-177.

16. Haig AJ, Tomkins CC (2010) Diagnosis and management of lumbar spinal stenosis. JAMA 303: 71-72.

17. Reiman MP, Harris JY, Cleland JA (2009) Manual therapy interventions fo patients with lumbar spinal stenosis: A systematic review. New Zealand J Physiother 37: 17-28.

18. Balakatounis KC, Panagiotopoulou KA, Mitsiokapa EA, Mavrogenis AF Angoules AG, et al. (2011) Evidence-based evaluation and current practice of non-operative treatment strategies for lumbar stenosis. Folia Medica 53: 5-14.

19. Kalff R, Ewald C, Waschke A, Gobisch L, Hopf C (2013) Degenerative lumbar spinal stenosis in older people: Current treatment options. Dtsch Arztebl Int 110: 613-623.

20. Sullivan PO, Dankaerts W, Burnett A, Straker L, Bargon G, et al. (2006) Lumbopelvic kinematics and trunk muscle activity during sitting on stable and unstable surfaces. J Orthop Sports Phys Ther 36: 19-25.

21. Low J, Reed A (2006) Electrical stimulation of nerve and muscle. Electrotherapy explained: Principles and practice, 3rd ed. Butterworth-Heinemann (Elsevier) 123.

22. Dehghan M, Farahbod F (2014) The efficacy of thermotherapy and cryotherapy on pain relief in patients with acute low back pain: A clinical trial study. J Clin Diagn Res 8: LC01-04.

23. Boyd B, Villa PS (2012) Normal inter-limb differences during the straight leg raise neurodynamic test: A cross sectional study. BMC Musculoskelet Disord 13: 245 .

24. Malik N, Kataria C, Sachdeva NB (2012) Comparative effectiveness of straight leg raise and slump stretching in subjects with low back pain with adverse neural tension. Int J Health Rehabil Sci 1: 2-10.

25. Fritz JM, Erhard RE, Vignovic M (1997) A nonsurgical treatment approach fo patients with lumbar spinal stenosis. Physther 77: 962-973. 